\title{
FQSPM-SWOT FOR STRATEGIC ALLIANCE PLANNING AND PARTNER SELECTION; CASE STUDY IN A HOLDING CAR MANUFACTURER COMPANY
}

\author{
Peyman AKHAVAN ${ }^{a}$, Sasan BARAK ${ }^{\mathrm{b}}$, Hamidreza MAGHSOUDLOU ${ }^{c}$, \\ Jurgita ANTUCHEVIČIENE்
}

a Department of Management, Malek Ashtar University of Technology, Tehran, Iran,

${ }^{b}$ Faculty of Economics, Technical University Ostrava, Ostrava, Czech Republic

${ }^{c}$ Faculty of Industrial and Mechanical Engineering, Qazvin Branch, Islamic Azad University, Qazvin, Iran

${ }^{\mathrm{d} D e p a r t m e n t ~ o f ~ C o n s t r u c t i o n ~ T e c h n o l o g y ~ a n d ~ M a n a g e m e n t, ~ V i l n i u s ~ G e d i m i n a s ~ T e c h n i c a l ~ U n i v e r s i t y, ~}$ Vilnius, Lithuania

Received 12 March 2014; accepted 22 June 2014

\begin{abstract}
In today's competitive environment, holding companies are usually unable to successfully compete in production of goods and services due to technological sophistication. Therefore, for success of holding companies, selecting appropriate strategic alliance partner is a critical factor. Accordingly, the aim of the paper is to propose a systematic approach for an effective partner selection. Firstly, the underlying motivation and reasons for a strategic alliance building are presented using a SWOT analysis. Criteria of partners' evaluation are attained on the basis of combining strengths, weaknesses, opportunities and threats. Due to uncertainty of criteria, they are weighted using fuzzy quantitative strategic planning matrix (FQSPM). Because of a large number of criteria obtained from the SWOT-FQSPM analysis, criteria are diminished based on their weights using the Gap analysis with fuzzy data ranking. In the next step, it is proposed to apply four ranking algorithms including the Fuzzy Additive Ratio Assessment (ARAS-F), the Fuzzy Complex Proportional Assessment (COPRAS-F), the Fuzzy Multi-Objective Optimization by Ratio Analysis (Fuzzy MOORA), and the Fuzzy Technique for Order Preference by Similarity to Ideal solution (Fuzzy TOPSIS) to evaluate strategic partners. Finally, the results are combined with the help of the Borda method to choose the best alternative. To illustrate the efficiency of the proposed approach, a real partner selection problem at a holding industries factory in Iran is presented.
\end{abstract}

Keywords: partner selection, strategic alliance, SWOT, FQSPM, MCDM, ARAS-F, COPRAS-F, Fuzzy MOORA, Fuzzy TOPSIS.

JEL Classification: C44, C81, C82, D81.

Corresponding author Jurgita Antuchevičienè

E-mail: jurgita.antucheviciene@vgtu.lt 


\section{Introduction}

Many manufacturer and service organisations depend on each other when producing goods and supplying services. If it is assumed that continuous progress of any organisation depends on the ratio of quality superiority of its products or services in comparison to competitors, it may be concluded that such advantage could not be gained without cooperation with an appropriate partner. For this reason, companies usually attempt to conclude an alliance contract with smaller companies as strategic alliance partners under companies' business brand. This type of business cooperation or acquisition is aimed at production of enhanced competitive products using more advanced technologies of smaller companies that would make the holding company more active and thriving in the competition against large rival companies (Cummings, Holmberg 2012). Accordingly, the most important factor is the selection of appropriate partners for holding companies to attain success in a dynamic business environment. Even the superior alliance management may be insufficient to overcome poor initial partner screening and selection efforts (Ashayeri et al. 2012). There are several reasons for the successful implementation of strategic alliances, but the importance of partner selection has been emphasised (Medcof 1997; Ding et al. 2013).

Based on existing approaches to cooperation and the use of capabilities and capacities of a company and its partners, a partner should be selected using systematic rules and viable criteria to ensure the minimal risk of outsourcing activities. As a systematic approach, many studies (Hoffmann, Schlosser 2001; Sampson 2004) advise companies to determine their motivation prior to selecting an appropriate alliance partner. This implies that the importance of selection criteria is affected by motivation. Nevertheless, almost all studies in this field also use expert ideas for determining motivation and determining or evaluating criteria of partners.

Therefore in the current research, based on the systematic approach, it is proposed to use a SWOT (Strengths, Weaknesses, Opportunities and Threats) analysis as a motivation definer for alliance strategy building with implementation of the quantitative strategic planning matrix, i.e. the QSPM-Gap analysis for weighting and determining the most important and feasible strategies as criteria for partner selection. It is important to note that in contrast with other studies, which use expert ideas only for identification of a strategic alliance, the current research seeks to achieve this aim with the help of the SWOT with QSPM analysis, combined with expert opinions. Then, the Gap analysis is used for selection of the most important criteria based on their feasibility score and QSPM weighted score.

Rather often, problems related to partner selection are examined using Multiple Criteria Decision Making (MCDM) approaches. There are some studies in this field that use new prioritisation methods. The relevant research review can be found in the following section of the article. It should also be noted that results can differ depending on the use of different MCDM methods (Antucheviciene et al. 2011, 2012). However, the use of a single prioritisation method cannot ensure the best result; besides, such a result would not be robust. Since we need a robust decision-making to choose the best partner (alternative), it is proposed to rank them using ARAS-F, COPRAS-F, Fuzzy MOORA, and Fuzzy TOPSIS methods. Then, the overall results can be found based on the Borda method. It should be mentioned, that this study was the first to use ARAS-F, COPRAS-F and Fuzzy MOORA methods for partner selection. 
The rest of the paper is organised as follows: the first section presents the literature review; the proposed model is described in detail in the second section; in the third section, a case study is presented and the result obtained from the proposed algorithm is described; and the final section offers conclusions and future efforts.

\section{Literature review}

\subsection{Partner selection}

In this "co-competition" era, competitive advantages rely not only on internal capability and resources, but also on a close cooperation and solid relationships with external organisations (Claycomb, Frankwick 2004). Therefore, it is of vital importance to select the right partners for a strategic alliance that would result in minimisation of the total cost of produced goods as well as maximised profits and the quality of products.

Although policies on strategic alliances have been adopted by companies for decades, Gonzalez (2001) found that only 50\% or less of alliance participants considered such integration a success. Some reports indicate that most of strategic alliance failures result from partner inability to perform the assigned function. When an enterprise decides to form a strategic alliance, it should select the partner with extreme caution in order to ensure success.

As a result, researchers use various methods to solve partner selection problem with respect to considerations mentioned above. Table 1 reviews partner selection studies, applied methods and considered problems.

The review indicates studies that use up-to-date Multiple Criteria Decisions Making approaches, such as ARAS (Zavadskas, Turskis 2010), COPRAS (Zavadskas, Kaklauskas 1996), Step-wise Weight Assessment Ratio Analysis (SWARA) (Keršuliene et al. 2010), Multi-Objective Optimization by Ratio Analysis (MOORA) (Brauers, Zavadskas 2006) and MULTIMOORA (Brauers, Zavadskas 2010), etc.

\subsection{SWOT}

In the partner selection process, the first step is devoted to a strategic analysis of internal organisational and external environmental driving forces, which act as the underlying motivation and reasons for alliance formation. This can be achieved using a systematic and simple method, such as a SWOT analysis.

A SWOT analysis is a generally used tool which examines strengths and weaknesses of an organisation or industry together with opportunities and threats of their marketplace environment (Azimi et al. 2011). Selection of important partners requires comprehensive information on circumstances of a market and a company; in addition, strategies of an organisation should be identified based on a scientific and systematic method. Thus, a SWOT analysis could be useful for determining important motivation of a company in partner selection. Having identified this motivation, strategies can be developed considering strengths, eliminating weaknesses, exploiting opportunities or countering threats (Kandakoglu et al. 2009) as well as using criteria that help companies evaluate their partners. It is important 
to note that there are hardly any SWOT analysis studies in partner selection. On the other hand, empirical studies show that the analysis is used successfully in designing real world problems (Yüksel, Dağdeviren 2007).

Table 1. Partner selection studies

\begin{tabular}{|c|c|c|}
\hline References & Method & Considered problem \\
\hline (Liou et al. 2011) & $\begin{array}{l}\text { Fuzzy preference } \\
\text { programming and Analytic } \\
\text { Network Process (ANP) }\end{array}$ & $\begin{array}{l}\text { To select partners for strategic alliances in } \\
\text { the airline industry by considering effects } \\
\text { of uncertainty and disagreement between } \\
\text { decision-makers }\end{array}$ \\
\hline (Huang et al. 2010) & $\begin{array}{l}\text { Multi objective } \\
\text { programming }\end{array}$ & $\begin{array}{l}\text { To select optimal partners in the alliance } \\
\text { and the corresponding resource allocations }\end{array}$ \\
\hline (Chen et al. 2010) & $\begin{array}{l}\text { Analytic hierarchy process } \\
\text { (AHP) with linguistic } \\
\text { variables }\end{array}$ & $\begin{array}{l}\text { To select an R\&D strategic alliance with } \\
\text { closer levels of performance }\end{array}$ \\
\hline (Ye 2010) & $\begin{array}{l}\text { TOPSIS with interval- } \\
\text { valued intuitionistic } \\
\text { numbers }\end{array}$ & $\begin{array}{l}\text { To select suitable partner for a virtual } \\
\text { enterprise }\end{array}$ \\
\hline (Wu et al. 2009) & ANP & $\begin{array}{l}\text { Evaluate criteria and sub-criteria of } \\
\text { partner in the LCD industry }\end{array}$ \\
\hline (Liou 2012) & $\begin{array}{l}\text { Hybrid DEMATEL and } \\
\text { ANP }\end{array}$ & $\begin{array}{l}\text { Helps to select suitable partners for a } \\
\text { Taiwanese airline }\end{array}$ \\
\hline (Yue 2013) & Projection technique & $\begin{array}{l}\text { To select a partner with linguistic values } \\
\text { and intuitionistic fuzzy information under } \\
\text { a group decision-making environment }\end{array}$ \\
\hline (Geum et al. 2013) & Index-based approach & $\begin{array}{l}\text { Used index-based approach for patents } \\
\text { and publications to identify and evaluate } \\
\text { strategic partners for collaborative } R \& D\end{array}$ \\
\hline (Büyüközkan et al. 2008) & AHP and TOPSIS & $\begin{array}{l}\text { Determine the most important criteria } \\
\text { after calculating the criteria weights by } \\
\text { AHP and finally ranking the strategic } \\
\text { alliance partner in the logistics value } \\
\text { chain by TOPSIS }\end{array}$ \\
\hline (Chen et al. 2011) & Fuzzy PROMETHEE & $\begin{array}{l}\text { To evaluate four potential vendors using } \\
\text { seven criteria and four decision makers } \\
\text { in the IS outsourcing }\end{array}$ \\
\hline (Chen, Wang 2009) & Fuzzy VIKOR & $\begin{array}{l}\text { Provides a rational and systematic process } \\
\text { for developing the best alternative and } \\
\text { compromise solution under each of the } \\
\text { selection criteria for optimised partner } \\
\text { in IT outsourcing }\end{array}$ \\
\hline (Ashayeri et al. 2012) & $\begin{array}{l}\text { Intuitionistic fuzzy } \\
\text { Choquet integral operator }\end{array}$ & $\begin{array}{l}\text { Development of the value chain concept } \\
\text { from the perspective of partner selection. } \\
\text { Outlines general similarities and } \\
\text { differences of the value chain and the } \\
\text { SCOR, and uses a simple V-form supply } \\
\text { chain example to establish the proposed } \\
\text { approach }\end{array}$ \\
\hline
\end{tabular}




\subsection{QSPM with the Gap analysis}

Although a SWOT analysis is a powerful tool, some experts believe that the number of quadruplet strategies resulting from the SWOT matrix are mostly too large. The number of these strategies should be reduced. Yet, a usual SWOT analysis cannot sort or weight strategies by using quantitative methods. Also, for having feasible criteria which are used as alliance strategies, a screening after criteria weighting is inevitable.

In order to solve these shortcomings particular to a SWOT analysis, the quantitative strategic planning matrix (QSPM) with the Gap analysis can be applied. It could be an effective tool when integrated with a SWOT analysis. The QSPM-Gap analysis evaluates, weights and reduces the number of criteria by examining feasibility and consistency of strategic alliance criteria in facing with environmental conditions and organisational situations. Accordingly, major criteria for the evaluation of partners will be formulated applying this approach.

Generally, studies in this field do not use any specific methods. Important criteria are only selected based on expert ideas and preferences. Moreover, in some cases when a number of strategies is large, decision makers can have different justification that causes inherent conflicts. Accordingly, it is proposed to use the Fuzzy QSPM-Gap analysis to adjust this condition and to decrease uncertainty and disagreement.

Recently, some researchers used the Fuzzy QSPM matrix to identify important strategies. Hosseini Nasab and Milani (2012) applied multiple criteria decision making and fuzzy numbers for improvement of a QSPM matrix. In their research, a FQSPM matrix is used for computing the sum of the total attractiveness score of alternatives. Yazdani et al. (2012) designed a strategic plan in an Iranian engineering company applying a SWOT analysis with reliable and achievable test by using QSPM.

\section{The proposed model for partner selection}

As mentioned before, since motivation to establish strategic alliances depends on different needs of an enterprise, attempts to identify universal criteria that enterprises should employ when seeking a proper partner are not productive (Chen et al. 2010). Accordingly, in the current research, the underlying motivation and reasons for strategic alliance building are elaborated with the help of a SWOT analysis and are determined according to exact wishes of a company. Then, criteria for evaluation of partners are attained on the basis of pair combining of four motivation groups of strengths, weaknesses, opportunities and threats. Figure 1 shows the proposed idea.

In the current research, criteria are obtained directly from motivation and do not require any reciprocal analysis as in studies of Liou et al. (2011) and Chen et al. (2010). Also, based on a direct linkage between criteria and motivation, inconsistency errors do not emerge. The criteria are extracted from external and internal motivation. If a partner does not satisfy such motivation, the alliance will break down.

Once the criteria are investigated, the weighting and feasibility evaluation process is completed using the QSPM-Gap analysis. (Due to uncertainty of examined criteria, criteria are weighted using the FQSPM matrix.) The steps of analysis are as follow: 


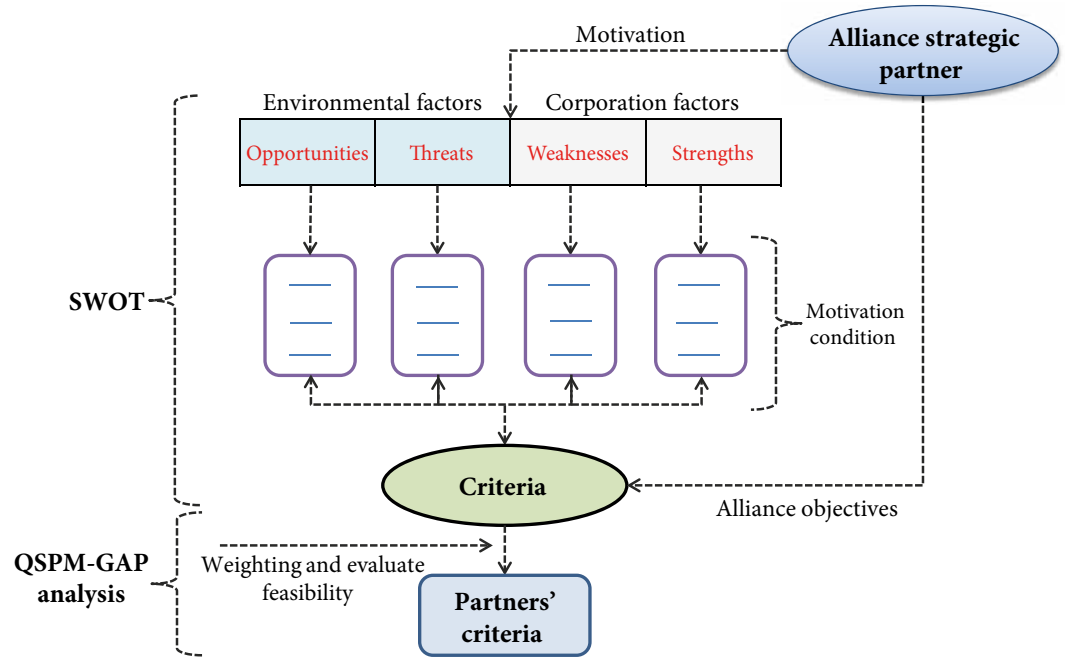

Fig. 1. The first step of the model

1. Create a table of alliance strategies (SO, WO, ST, WT) as criteria and motivations (S, O, $\mathrm{W}, \mathrm{T}$ ) based on the SWOT analysis output as in Table 2.

Table 2. Fuzzy SWOT-QSPM chart

\begin{tabular}{l|l|l|l|l|l}
\hline & Att. score & $\mathrm{SO}_{1}-\mathrm{SO}_{m}$ & $\mathrm{WO}_{1}-\mathrm{WO}_{m}$ & $\mathrm{ST}_{1}-\mathrm{ST}_{m}$ & $\mathrm{WT}_{1}-\mathrm{WT}_{m}$ \\
\hline $\mathrm{S}_{1}-\mathrm{S}_{n}$ & & & & & \\
\hline $\mathrm{W}_{1}-\mathrm{W}_{n}$ & & & & & \\
\hline $\mathrm{O}_{1}-\mathrm{O}_{n}$ & & & & & \\
\hline $\mathrm{T}_{1}-\mathrm{T}_{n}$ & & & & & \\
\hline Total criteria score & & & & & \\
\hline Feasibility score & & & & & \\
\hline Criteria weight & & & & & \\
\hline
\end{tabular}

2. Determine attractiveness scores of any of motivations $(\mathrm{S}, \mathrm{W}, \mathrm{O}, \mathrm{T})$ using fuzzy scores. These scores are determined in respect to environment and corporation factors.

3. Determine fuzzy scores of criteria (alliance strategies) in respect to motivations.

4. Compute normalised attractiveness score of any of motivations using the following equation:

$$
\bar{A}_{i}^{p}=\frac{A_{i}^{p}}{\sum_{i=1}^{N} A_{i}^{p}}, p \in(l, m, u), i=1,2, \ldots, N
$$

where $N$ is the number of motivations and $A_{i}$ is fuzzy attractiveness scores of $i^{\text {th }}$ motivation.

5. Calculate the normalised criteria score by using the following equation:

$$
\hat{x}_{i j}^{p}=\bar{A}_{i}^{p} x_{i j}^{p}, p \in(l, m, u), i=1,2, \ldots, N, j=1,2, \ldots, M,
$$

where $M$ is the number of criteria, $x_{i j}$ represents fuzzy scores of $i^{\text {th }}$ motivation of $j^{\text {th }}$ criteria, and $\bar{A}_{i}^{p}$ is the normalised attractiveness score of $i^{\text {th }}$ motivation. 
6. Compute the total criteria score of any of criteria using the following equation:

$$
\operatorname{TCS}_{j}^{p}=\sqrt[1 / N]{\prod_{i=1}^{N} \hat{x}_{i j}^{p}}, p \in(l, m, u), i=1,2, \ldots, N, j=1,2, \ldots, M .
$$

7. Determine the feasibility scores of criteria in facing with experts' idea about alliance condition and criteria situation. This score is the feasible degree of criteria regarding the alliance condition in the case study.

8. Multiplying the total score of each criterion $T C S_{j}^{p}$ by the its feasibility degree, which makes fuzzy criteria weights:

$$
W_{j}^{p}=\operatorname{TCS}_{j}^{p} \times f_{j}, \quad p \in(l, m, u), \quad i=1,2, \ldots, N,
$$

where $W_{j}$ is weight of $j^{\text {th }}$ criteria, $T C S_{j}^{p}$ is the total score of $j^{\text {th }}$ criteria and $f_{j}$ is the feasibility degree of $j^{\text {th }}$ criteria.

9. In this step, we use the Gap analysis based on fuzzy ranking as follows:

9.1. The values of $M_{i}\left(l_{i}, m_{i}, u_{i}\right)$ to $M_{j}\left(l_{j}, m_{j}, u_{j}\right)$ criteria can be equivalently expressed as follows (Tavana et al. 2013):

$$
V\left(M_{i} \leq M_{j}\right)=h g t\left(M_{j} \cap M_{j}\right)=\mu M_{i}(d)=\left\{\begin{array}{lr}
1, & \text { if } m_{j} \geq m_{i}, \\
0, & \text { if } l_{i} \geq u_{j}, \\
\frac{u_{i}-l_{j}}{\left(m_{j}-u_{j}\right)-\left(m_{i}-u_{i}\right)} \text { otherwise, }
\end{array}\right.
$$

where $d$ is the ordinate of the highest intersection point D between $\mu M_{i}$ and $\mu M_{j}$ (see Fig. 2).

To compare $M_{i}$ and $M_{j}$, both the values of $V\left(M_{i} \geq M_{j}\right)$ and $V\left(M_{i} \leq M_{j}\right)$ are required.

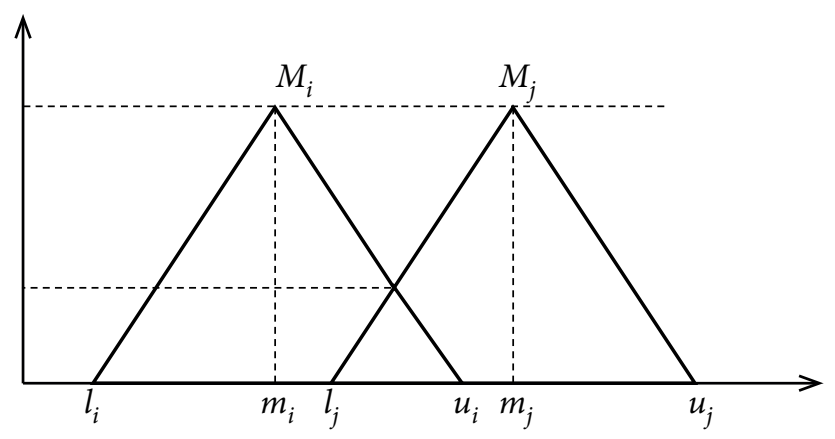

Fig. 2. Highest intersection point D between $\mu M_{i}$ and $\mu M_{j}$

9.2. The degree of possibility for a convex fuzzy number to be greater than $N$ convex fuzzy numbers $m_{i}(i=1,2, \ldots, N)$ can be defined by Eq. 6 :

$V\left(M \geq M_{1}, M_{2}, \ldots, M_{N}\right)=V\left[\left(M \geq M_{1}\right),\left(M \geq M_{2}\right), \ldots,\left(M \geq M_{N}\right)\right]=\min V\left(M \geq M_{i}\right),(6)$ where $i=1,2, \ldots, N$. 
9.3. For $K \neq i$ and $K=1,2, \ldots, N, G W_{j}=\min V\left(M_{i} \geq M_{K}\right)$, then, the Gap weight is as follows:

$$
G W_{j}=\left(G W_{1}, G W_{2}, \ldots, G W_{M}\right), j=1,2, \ldots, M
$$

9.4. Compute the weighted normalised Gap of any criteria using the following equation:

$$
N G W_{j}=\frac{G W_{j}}{\sum_{j=1}^{m} G W_{j}} .
$$

Criteria with higher $N W G_{i}$ have more priority than others. We select the most important criteria, based on expert ideas, which offer that roughly $80 \%$ of the cumulative weight of criteria can present all the most effective criteria.

Once the criteria are investigated, some choices of appropriate partners for strategic alliance formation are considered. Then, the evaluation of the alliance is fed back into the analytical phase. We seek to determine, which of several alternatives would best support the realisation of the ultimate goal. For these reasons, MCDM methods could be used.

Criteria determined in the previous stage and their fuzzy weights are used as input of ARAS-F, COPRAS-F, Fuzzy MOORA, and Fuzzy TOPSIS methods, and the Borda method is used to select the best partners as shown in Figure 3.

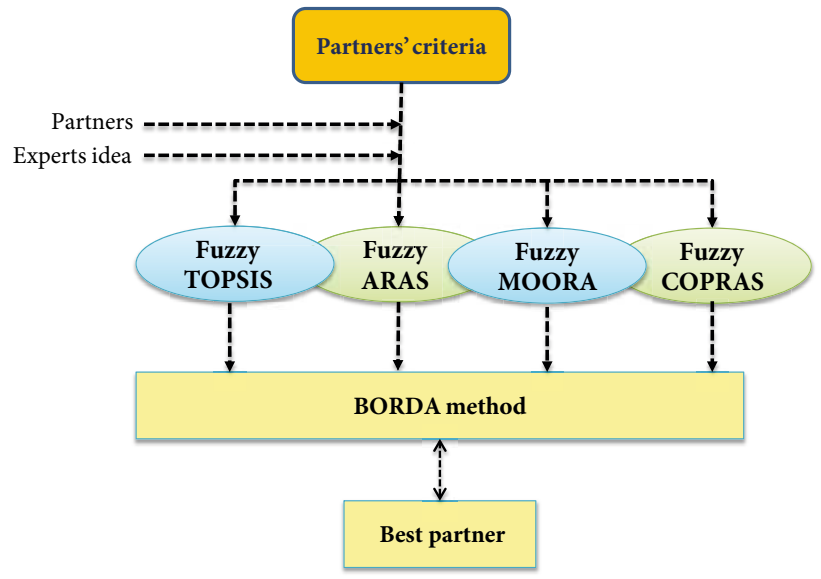

Fig. 3. The second step of the model

The proposed procedure for partner selection is summarised below.

Step 1: Set up an expert committee for this strategic decision problem.

Step 2: Set the fuzzy scale based on linguistic variables for SWOT, QSPM, ARAS, COPRAS, MOORA and TOPSIS methods.

Step 3: Get criteria based on the SWOT analysis and company motivation as follow:

1. Determine the key opportunities obtained as a result of partner selection;

2. Determine the key threats incurred by partner selection; 
3. Determine the key weaknesses of the company;

4. Determine the key strengths of the company;

5. Compare internal strengths with external opportunities and determine the most effective SO alliance strategies;

6. Compare internal weaknesses and external opportunities and determine the most effective WO alliance strategies;

7. Compare internal strengths and external threats and determine the most effective ST alliance strategies;

8. Compare internal weaknesses and external threats and determine effective (defective) WT factors;

9. Determine SO, WO, ST and WT as alliance strategy criteria.

Step 4: Input criteria into the fuzzy QSPM matrix and weight them.

Step 5: Reduce the number of criteria by examining feasibility using the Gap analysis based on fuzzy ranking.

Step 6: Get partners' criteria.

Step 7: Evaluate the performance for each of the potential partners using ARAS-F, COPRAS-F, Fuzzy MOORA and Fuzzy TOPSIS methods based on partners' criteria.

Step 8: Compound results of the methods and get the final results based on the Borda method.

In summary, the proposed approach is divided into three sections: strategy building, alliance strategy weighting and decreasing, and partner evaluation and selection.

\section{Case study: strategic alliance planning for partner selection in a holding car manufacturer company}

With respect to the productive nature of car industries and the fact that they are aimed at achieving a greater product demand on the market, holding companies try to increase the profitability and reduce the production cost when entering into contracts with lucrative small and medium enterprises (SMEs) that satisfy required conditions under their own brand name. Also, establishing alliances with other companies may be a feasible way for SMEs to acquire necessary assistance for R\&D. Because the size of SMEs, they have high focus on some specific technology and can be a proper partner for big companies. This study was completed at SH.KH Company that produces heavy machinery in Iran. This company works with casting units and production of cranks. SH.KH Company is attempting to acquire the Middle East market and concentrates on contracts with suitable SMEs. This contract is concluded under the name of SH.KH in the field of producing casting units and cranks.

Company strategies obtained from the SWOT analysis are introduced in Table 3. A group of experts answered questionnaires, which included open and close answers. The survey was conducted with three levels of managers. The result of the survey provided the basis for the SWOT analysis which was used to identify motivation and criteria of the company for cooperation with other companies (partners). 
Table 3. SWOT Analysis

\begin{tabular}{l}
\hline External factor \\
\hline Weaknesses: \\
1. Lack of appropriate mechanism in \\
order to prepare spare parts inside \\
the country. \\
2. Lack of new production equip- \\
ment. \\
3. Reliance on a customer and the \\
lack of marketing in internal and \\
international markets. \\
4. Shortage of delegation in all \\
country. \\
5. Lack of information about updated \\
price of spare parts. \\
6. Lack of mechanised logistic opera- \\
tions (such as a lift truck). \\
7. Space and technology restrictions \\
to increase production capacity. \\
8. Low investing power due to high \\
investment in preparing foreign \\
spare parts. \\
9. Weakness in maintenance (lack \\
of mechanised system and low \\
competence of human resources). \\
10. Lack of coordination and com- \\
plete information circulation \\
between different departments.
\end{tabular}

Opportunities:

1. Supporting policies of the government on renovation and expansion of public transportation.

2. Preferential rate of customs duty on imported parts.

3. Using the existing and the new brand.

4. Government supporting policy for export.

5. Increasing attention to the environment and decreasing fuel consumption.

6. Increasing population and $\mathrm{mi}-$ gration to cities.

7. The Iranian Government Decision of 2010 on phasing out old cars.

8. Privatisation approach used by the government.

9. Banking facilities and foreign exchange reserves.

10. Applying advanced technologies for engines.

Strengths:

1. Outsourced training of human resources.

2. Remarkable scientific capabilities in performing research and development projects.

3. Establishment of internal network system and its promotion capabilities.

4. A customer representative in the company.

5. Suitable equipment for staff training.

6. Flexibility of producing crank, assembling and spare parts making.

7. Certainty on dominance and on the quality of services and attempts to get quality management standard in services.

8. SH.KH Company is exempt from customs duties on imported spare parts.

\section{WO criteria}

1. Automated systems for high volumes of production.

2. Having guiding costs of major production processes in order to increase competing power.

3. Ability to reengineer after selling services.

4. Establishing up to date management methods.

5. Ability to replace new equipment with old equipment and mechanisation in order to increase the production capacity.

6. Ability to create a network, diversify and disperse sales centres in the country and abroad.

\section{SO criteria}

1. Ability to increase production capacity.

2. Diversify sales via expansion of export and new product development.

3. Help to increase marketing power to have effective representation in regional markets.

4. Expansion of productivity and incentive systems.

5. Relationships with other industries and expanding industrial marketing activities. 
Continued Table 3

\begin{tabular}{|c|c|c|}
\hline External factor & Internal fac & \\
\hline Threats: & WT criteria & ST criteria \\
\hline $\begin{array}{l}\text { 1. Restrictions for importing spare } \\
\text { parts from foreign countries. } \\
\text { 2. Rapid technological changes } \\
\text { in car industry on the global } \\
\text { scale. } \\
\text { 3. Economic sanctions from } \\
\text { countries of technology own- } \\
\text { ers in the field of technology } \\
\text { transfer. } \\
\text { 4. Importing buses by govern- } \\
\text { ment. } \\
\text { 5. Strict environmental require- } \\
\text { ments. } \\
\text { 6. Rapid emergence of competi- } \\
\text { tors from advanced world } \\
\text { technologies. } \\
\text { 7. Administrative changes in } \\
\text { customs related to car import. } \\
\text { 8. Changing attitudes toward } \\
\text { ownership of luxury and pri- } \\
\text { vate cars. } \\
\text { 9. Globalization. }\end{array}$ & $\begin{array}{l}\text { 1. Obtain new technologies to ensure } \\
\text { their availability. } \\
\text { 2. Utilising capacity of other manu- } \\
\text { facturers to expand services to } \\
\text { suppliers. } \\
\text { 3. Creating specialised production } \\
\text { units with technologic flexibility } \\
\text { capability for different industrial } \\
\text { products. } \\
\text { 4. Reengineering of organisational } \\
\text { structures and relations. }\end{array}$ & $\begin{array}{l}\text { 1. Having diverse suppliers. } \\
\text { 2. Supplying spare parts } \\
\text { inside the country. } \\
\text { 3. Partnership with the } \\
\text { global network of sup- } \\
\text { pliers. } \\
\text { 4. Diverse production like } \\
\text { special cars and public } \\
\text { city transportation cars } \\
\text { depending on the avail- } \\
\text { able technology in a } \\
\text { company. } \\
\text { 5. Optimised supply chain } \\
\text { and management of hu- } \\
\text { man resources. }\end{array}$ \\
\hline
\end{tabular}

Linguistic variables for fuzzy scale of the expert idea are offered in Table 4.

Table 5 illustrates a part of the original QSPM matrix, which shows results of pairwise comparisons of criteria. Notice that quantitative calculations of the QSPM matrix and the SWOT analysis are performed using two methods:

1. Obtaining suggestions of seven experts through discreet interviews;

2. Gathering information from fifty experts filling-in the questionnaire.

Table 4. Linguistic variables for fuzzy scale

\begin{tabular}{ccccccc}
\hline Condition & $\begin{array}{c}\text { Very poor } \\
(\mathrm{VP})\end{array}$ & $\begin{array}{c}\text { Poor } \\
(\mathrm{P})\end{array}$ & $\begin{array}{c}\text { Fair } \\
(\mathrm{F})\end{array}$ & $\begin{array}{c}\text { Good } \\
(\mathrm{G})\end{array}$ & $\begin{array}{c}\text { Very good } \\
(\mathrm{VG})\end{array}$ & $\begin{array}{c}\text { Excellent } \\
(\mathrm{E})\end{array}$ \\
\hline Fuzzy scale & $(0,0.05,0.1)$ & $(0.1,0.25,0.3)$ & $(0.3,0.45,0.5)$ & $(0.5,0.65,0.7)$ & $(0.7,0.85,0.9)$ & $(0.9,0.95,1)$ \\
\hline
\end{tabular}

Table 5. A part of the original QSPM matrix

\begin{tabular}{cccccccccccc}
\hline & Att. & SO1 & SO2 & SO3 & SO4 & SO5 & WO1 & WO2 & WO3 & WO4 & $\ldots$ \\
\hline O1 & VG & G & VG & G & F & G & G & G & P & F & $\ldots$ \\
O2 & VG & VG & VG & P & G & F & G & VG & F & P & $\ldots$ \\
O3 & F & P & F & P & G & G & P & F & P & F & $\ldots$ \\
O4 & VG & VG & VG & G & G & G & G & G & F & G & $\ldots$ \\
$\cdots$ & $\cdots$ & $\cdots$ & $\cdots$ & $\cdots$ & $\cdots$ & $\cdots$ & $\cdots$ & $\cdots$ & $\cdots$ & $\cdots$ & $\cdots$ \\
\hline
\end{tabular}


In this step, the normalised attractiveness score and the normalised criteria score are obtained by Eq. (1) and Eq. (2), respectively. Then, the total criteria score based on Eq. (3) is exerted and the feasibility number for each criterion is suggested by experts. Multiplying the total criteria score by the feasibility degree Eq. (4) of each criterion, weighted criteria are obtained. Table 6 illustrates the results of the step. In this step, criteria have been ranked with the fuzzy ranking model Eq. (5-6) and Gap weights $\left(G W_{j}\right)$ as well as normalised Gap weights $\left(N G W_{j}\right)$ have been received based on Eq. (7-8), see Table 7. $N G W_{j}$ is a ratio and criteria with higher $N G W_{j}$ have more priority than others. For example, we get the SO1 Gap weight as follows:

$$
\begin{aligned}
& G W_{S O 1}=\min \left(M_{S O 1} \leq M_{S O 2}, M_{S O 3}, M_{S O 4}, M_{S O 5}, M_{W O 1}, M_{W O 2}, M_{W O 3}, M_{W O 4}, M_{W O 5},\right. \\
& \left.M_{W O 6}, M_{S T 1}, M_{S T 2}, M_{S T 3}, M_{S T 4}, M_{S T 5}, M_{W T 1}, M_{W T 2}, M_{W T 3}, M_{W T 4}\right)= \\
& \min (0.237,1,0.0959,0.285,1,1,1,0.2628,1,1,1,1,1,1,0.427,1,1,1,0.4879)=0.0959 .
\end{aligned}
$$

Table 6. Total criteria score, feasibility degree and weighted criteria

\begin{tabular}{cccccccc}
\hline & \multicolumn{3}{c}{ Total criteria score } & \multirow{2}{*}{ Feasibility } & \multicolumn{3}{c}{ Weighted criteria } \\
\cline { 1 - 1 } & $l$ & $m$ & $u$ & & $l$ & $m$ & $u$ \\
\hline SO1 & 0.01013 & 0.01500 & 0.01625 & 3 & 0.03039 & 0.04501 & 0.04875 \\
SO2 & 0.01002 & 0.01491 & 0.01647 & 4 & 0.04007 & 0.05963 & 0.06588 \\
SO3 & 0.00701 & 0.01176 & 0.01324 & 1 & 0.00701 & 0.01176 & 0.01324 \\
SO4 & 0.01165 & 0.01630 & 0.01777 & 4 & 0.04661 & 0.06520 & 0.07106 \\
SO5 & 0.00829 & 0.01322 & 0.01473 & 5 & 0.04143 & 0.06608 & 0.07365 \\
WO1 & 0.00607 & 0.01089 & 0.01238 & 2 & 0.01214 & 0.02177 & 0.02476 \\
$\cdots$ & $\cdots$ & $\cdots$ & $\cdots$ & $\cdots$ & $\cdots$ & $\cdots$ & $\cdots$ \\
\hline
\end{tabular}

Like SO1, Gap weight of other criteria is calculated and normalised in Table 7.

Based on expert ideas, which suggest that roughly $80 \%$ of cumulative weight of criteria can present all of the most effective criteria, we select them as feasible and effective partner criteria as follows:

$$
\begin{aligned}
& N G W_{S O 2}+N G W_{S O 4}+N G W_{S O 5}+N G W_{W O 2}+N G W_{W O 4}+N G W_{S T 5}++N G W_{W T 4}= \\
& (0.1087+0.1361+0.1401+0.1227+0.1211+0.0980+0.0911)=0.8223>0.80
\end{aligned}
$$

In Table 7, output of FQSPM-Gap analysis matrix is depicted. Criteria of SO4, SO2, SO5, WO2, WO4, ST5, and WT4 have more than $80 \%$ of cumulate weight of criteria $(82.32 \%)$ and are selected as partner criteria (Table 8 ). Also, the decision matrix is normalised and the results are shown in Table 8.

In this step, we enter into the second phase of our paper and introduce alternatives. We introduce 5 alternatives as SMEs, which cooperate as an alliance in our partner selection model. Then, fuzzy triangular numbers are assigned from $\tilde{1}$ to $\tilde{9}$ by experts to evaluate these alternatives. Creating long-term commercial activities between a company and SMEs is the final aim of this expert scoring. Table 9 presents $\tilde{1}$ to $\tilde{9}$ linguistic variables, which are used in evaluation of alternatives by applying ARAS-F, COPRAS-F, Fuzzy MOORA, 


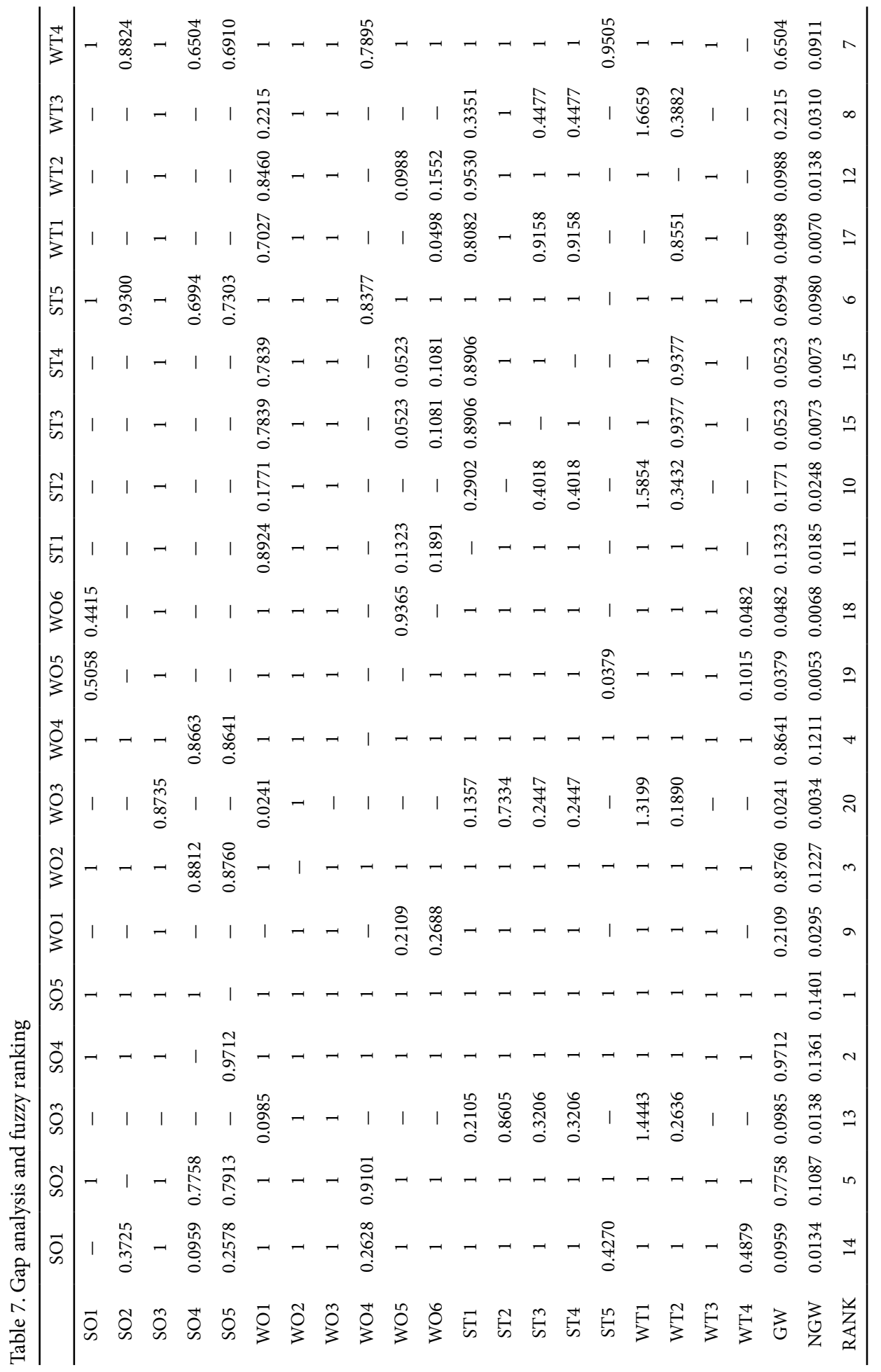


and Fuzzy TOPSIS methods. Table 10 also shows the fuzzy number value of alternatives in exchange for partner criteria by decision-makers.

Then, the alternative fuzzy numbers are normalised and normalised fuzzy decision matrix of five alternatives is obtained in Table 11.

In this stage, normalised-weighted values (normalised values multiplied by weights) of all the alternatives are calculated and normalised-weighted fuzzy decision making matrix is provided in Table 12.

Table 8. The fuzzy decision matrix and fuzzy weights of Partners' criteria

\begin{tabular}{ccccc}
\hline \multirow{2}{*}{ Criteria } & \multirow{2}{*}{ Criteria weights } & \multicolumn{3}{c}{ Normalised criteria weights } \\
\cline { 3 - 5 } & $(0.04007,0.05963,0.06588)$ & 0.138 & 0.139 & 0.139 \\
SO2 & $(0.04661,0.06520,0.07106)$ & 0.160 & 0.152 & 0.150 \\
SO4 & $(0.04143,0.06608,0.07365)$ & 0.142 & 0.154 & 0.156 \\
SO5 & $(0.04341,0.06229,0.06820)$ & 0.149 & 0.145 & 0.144 \\
WO2 & $(0.04272,0.06192,0.06788)$ & 0.147 & 0.144 & 0.144 \\
WO4 & $(0.03918,0.05785,0.06371)$ & 0.135 & 0.135 & 0.135 \\
ST5 & $(0.03768,0.05664,0.06255)$ & 0.129 & 0.132 & 0.132 \\
WT4 & & & &
\end{tabular}

Table 9. Linguistic variables of alternatives

\begin{tabular}{clccc}
\hline TFN & \multicolumn{1}{c}{ Linguistic variables } & Bottom & Medium & Top \\
\hline 1 & Equally preferred & 1 & 1 & 1 \\
2 & Equally to moderately preferred & 1 & 1.5 & 1.5 \\
3 & Moderately preferred & 1 & 2 & 2 \\
4 & Moderately to strongly preferred & 3 & 3.5 & 4 \\
5 & Strongly preferred & 3 & 4 & 4.5 \\
6 & Strongly to very strongly preferred & 3 & 4.5 & 5 \\
7 & Very strongly preferred & 5 & 5.5 & 6 \\
8 & Very strongly to extremely preferred & 5 & 6 & 7 \\
9 & Extremely preferred & 5 & 7 & 9 \\
\hline
\end{tabular}

Table 10. The fuzzy number of alternatives by decision makers

\begin{tabular}{cccccccc}
\hline & SO2 & SO4 & SO5 & WO2 & WO4 & ST5 & WT4 \\
\hline A1 & 9 & 9 & 2 & 2 & 4 & 3 & 7 \\
A2 & 7 & 5 & 3 & 4 & 7 & 4 & 5 \\
A3 & 6 & 9 & 2 & 3 & 3 & 5 & 6 \\
A4 & 6 & 7 & 4 & 3 & 7 & 4 & 8 \\
A5 & 9 & 4 & 3 & 4 & 4 & 3 & 9 \\
\hline
\end{tabular}




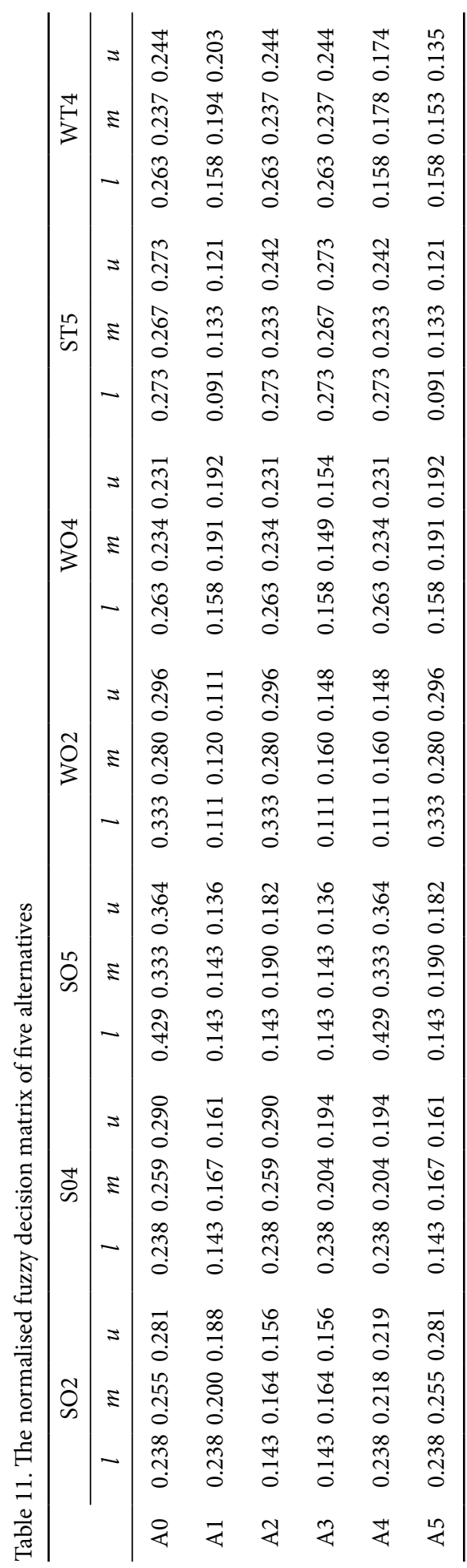

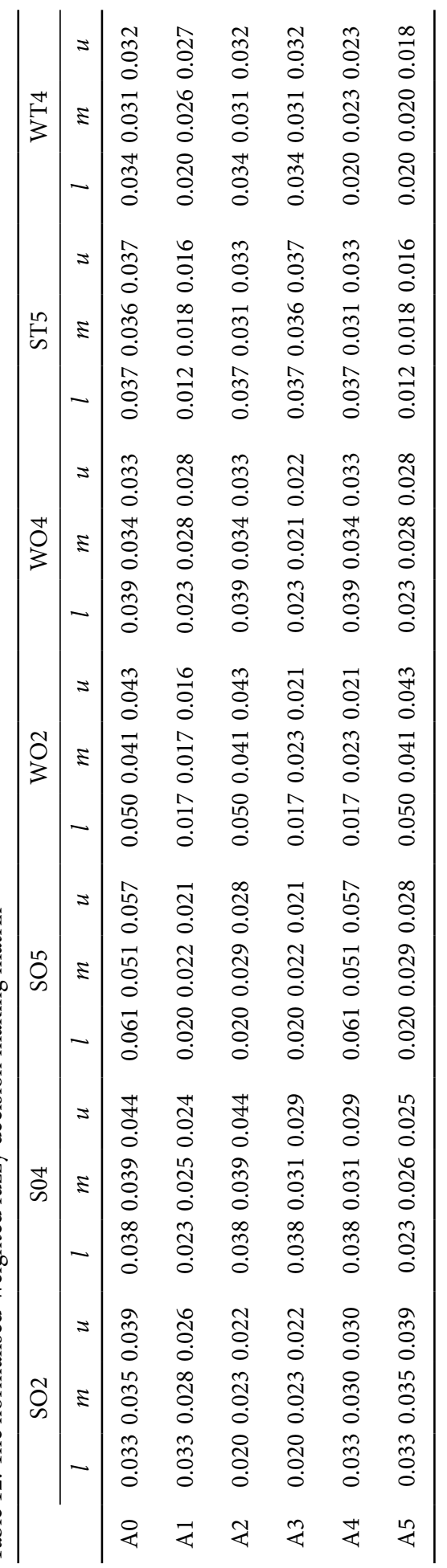


ARAS-F method results: One of the most effective recently developed method is ARAS (Additive Ratio Assessment) introduced by Zavadskas and Turskis (2010). Also, the same authors developed the ARAS-F method to solve different problems in fuzzy environment in transportation, construction, economics, technology and sustainable development (Zavadskas, Turskis 2010). The review by Zavadskas and Turskis (2011) provides a comprehensive comparison between the use of ARAS, COPRAS and other MCDM methods and their implementation in different fields. In the current case, the value of optimality function in the ARAS-F model for each criterion is determined and the results are shown in Table 13. Then, the centre-of-area algorithm is used for defuzzification of ARAS-F and the utility degree of an alternative $\left(k_{i}\right)$ is calculated.

The first row of Table 14 is a crisp value of the optimality function $\left(S_{i}\right)$, the next row is the degree of an alternative $\left(k_{i}\right)$ and the last row is the rank of the alternative.

Table 13. The value of optimality function resulting from the ARAS-F method

\begin{tabular}{lccc}
\hline & \multicolumn{3}{c}{ Value of optimality function } \\
\cline { 2 - 4 } & $l$ & $m$ & $u$ \\
\hline Partner 0 & 0.291 & 0.267 & 0.284 \\
Partner 1 & 0.148 & 0.164 & 0.158 \\
Partner 2 & 0.237 & 0.228 & 0.234 \\
Partner 3 & 0.189 & 0.187 & 0.185 \\
Partner 4 & 0.244 & 0.224 & 0.226 \\
Partner 5 & 0.182 & 0.197 & 0.197 \\
\hline
\end{tabular}

Table 14. The optimality function and the degree of an alternative value resulting from the ARAS-F method

\begin{tabular}{cccccc}
\hline & Partner 1 & Partner 2 & Partner 3 & Partner 4 & Partner 5 \\
\hline$S_{\mathrm{i}}$ & 0.166 & 0.219 & 0.181 & 0.211 & 0.218 \\
$k_{\mathrm{i}}$ & 0.629 & 0.832 & 0.687 & 0.801 & 0.830 \\
Rank & 5 & 1 & 4 & 3 & 2 \\
\hline
\end{tabular}

COPRAS-F method results: Calculations are made following Zavadskas and Antucheviciene (2007) and Safaei Ghadikolaei et al. (2014). In this method, based on Table 12, the total of weighted normalised value $\left(p_{i}\right)$ is calculated and the relative significance or priority value $\left(Q_{i}\right)$ for each partner alternative is computed (see Table 15). Finally, the utility degree $\left(N_{i}\right)$ for each alternative is calculated and the complete ranking of partners is obtained.

Table 15. The relative weight, utility degree and rank of each alternative resulting from the COPRAS-F method

\begin{tabular}{|c|c|c|c|c|c|c|}
\hline \multirow{2}{*}{ Partner } & \multicolumn{3}{|c|}{$p_{i}$} & \multirow{2}{*}{$Q_{i}$} & \multirow{2}{*}{$N_{i}$} & \multirow{2}{*}{ Rank } \\
\hline & $l$ & $m$ & $u$ & & & \\
\hline Partner 1 & 0.160 & 0.165 & 0.157 & 0.166 & 73.92 & 5 \\
\hline Partner 2 & 0.221 & 0.219 & 0.224 & 0.219 & 97.64 & 2 \\
\hline Partner 3 & 0.173 & 0.178 & 0.174 & 0.181 & 80.66 & 4 \\
\hline Partner 4 & 0.252 & 0.227 & 0.229 & 0.211 & 94.10 & 3 \\
\hline Partner 5 & 0.193 & 0.211 & 0.217 & 0.224 & 100 & 1 \\
\hline
\end{tabular}


Fuzzy TOPSIS method results: Calculations are made following Yurdakul and Iç (2009). In this method, based on Table 12, the negative and positive ideal solutions $\left(D^{+}, D^{-}\right)$are calculated and the ranking score $(C)$ is obtained. The results of the Fuzzy TOPSIS method are summarised in Table 16, which indicates that the partner 5 and partner 4 obtain the first and the second ranks with $C$ value of 0.595 and 0.587 , respectively.

Table 16. The ideal solution and the rank of each alternative resulting from the Fuzzy TOPSIS method

\begin{tabular}{ccccc}
\hline Partner & $D^{+}$ & $D^{-}$ & $C$ & Rank \\
\hline Partner 1 & 0.061 & 0.004 & 0.063 & 5 \\
Partner 2 & 0.037 & 0.043 & 0.535 & 3 \\
Partner 3 & 0.054 & 0.023 & 0.298 & 4 \\
Partner 4 & 0.027 & 0.038 & 0.587 & 2 \\
Partner 5 & 0.033 & 0.049 & 0.595 & 1 \\
\hline
\end{tabular}

Fuzzy MOORA method results: Calculations are made following Karande and Chakraborty (2012). In this method, based on Table 12, the beneficial criteria for each alternative $\left(S_{i}\right)$ are calculated, then, the defuzzification using the centre-of-area method is performed and finally, the rank of alternatives is obtained. Partner 5 and partner 2 get the first and second ranks, respectively (see Table 17).

Table 17. The beneficial criteria and the rank of each alternative resulting from the MOORA-F method

\begin{tabular}{cccccc}
\hline \multirow{2}{*}{ Partner } & \multicolumn{3}{c}{$S_{i}$} & \multirow{2}{*}{$S_{i}^{*}$} & \multirow{2}{*}{ Rank } \\
\cline { 2 - 4 } & $l$ & $m$ & 0.169 & 0.046 & 5 \\
\hline Partner 1 & 0.148 & 0.170 & 0.227 & 0.060 & 2 \\
Partner 2 & 0.219 & 0.222 & 0.189 & 0.056 & 4 \\
Partner 3 & 0.172 & 0.187 & 0.231 & 0.055 & 3 \\
Partner 4 & 0.227 & 0.224 & 0.203 & 0.071 & 1 \\
Partner 5 & 0.178 & 0.199 & 0.203 & \\
\hline
\end{tabular}

Comparative analysis: In order to validate the applicability and suitability of the four considered preference ranking methods to solve this partner selection problem, their ranking performance (see Table 18) is compared using the BORDA method.

Table 18. The ranking of alternatives with four methods

\begin{tabular}{ccccc}
\hline Partner & ARAS-F & COPRAS-F & Fuzzy TOPSIS & Fuzzy MOORA \\
\hline Partner 1 & 5 & 5 & 5 & 5 \\
Partner 2 & 1 & 2 & 3 & 2 \\
Partner 3 & 4 & 4 & 4 & 3 \\
Partner 4 & 3 & 3 & 2 & 4 \\
Partner 5 & 2 & 1 & 1 & 1 \\
\hline
\end{tabular}

Borda is one of consolidation methods that are based on the majority voting rule. In this research, the achieved rankings are consolidated by four methods of ARAS-F, COPRAS-F, Fuzzy TOPSIS, and Fuzzy MOORA. The results are presented in Table 19. For example, 
in Table 18, Partner 4 in ARAS-F, COPRAS-F and Fuzzy TOPSIS is better than Partner 3 and just in Fuzzy MOORA the results are inverse. Therefore, based on the majority voting, the $4^{\text {th }}$ row of the 3 rd column is equal to 1 in Table 19 . Then, we aggregate the results and the final alternative ranking is $\mathrm{A} 5 \succ \mathrm{A} 2 \succ \mathrm{A} 4 \succ \mathrm{A} 3 \succ \mathrm{A} 1$.

Table 19. Borda method for five alternatives

\begin{tabular}{cccccccc}
\hline & Partner 1 & Partner 2 & Partner 3 & Partner 4 & Partner 5 & BORDA & Rank \\
\hline Partner 1 & - & 0 & 0 & 0 & 0 & 0 & 5 \\
Partner 2 & 1 & - & 1 & 1 & 0 & 3 & 2 \\
Partner 3 & 1 & 0 & - & 0 & 0 & 1 & 4 \\
Partner 4 & 1 & 0 & 1 & - & 0 & 2 & 3 \\
Partner 5 & 1 & 1 & 1 & 1 & - & 4 & 1 \\
\hline
\end{tabular}

\section{Conclusions and future efforts}

Seeking for a better alliance partner for a strategic partnership, continuous controlling of their efficacy and helping them to expand efficacy of related activities to perform successful outsourcing is essential.

Therefore, the current research proposed to use SWOT, FQSPM-Gap, and combination of four fuzzy MCDM methods as an integrated methodology for solving partner selection problem. The SWOT analysis was used for determining motivation and criteria. Because the method is unable to identify the importance of each criterion, the QSPM-Gap analysis method under fuzzy environment was applied. By applying this method, the total weights of criteria obtained and the Gap analysis for decreasing the criteria was done using fuzzy ranking models. The weights of decreased criteria represent the real importance of each criterion in selecting the best partner.

In stage of ranking of alternatives based on weights of criteria, four methods, namely ARAS-F, COPRAS-F, Fuzzy TOPSIS and Fuzzy MOORA, together with the Borda algorithm were integrated to prioritise the alternatives.

The empirical results indicate that Partner 5 is the best selection from the car manufacturer's viewpoint. However, joining an alliance does not only depend on the company's "willingness", but also on "acceptance" of the alliance. Therefore, a tool is provided to help the car manufacturer to select an optimised strategic alliance.

This hybrid decision making process is performed as a possible appropriate form. It is obvious that the presented framework for ranking partners with respect to their total performance and considering dependence of criteria is a practical model.

Also, researchers can use other MCDM methods or develop hybrid approaches to solve the same problem and to compare with the proposed approach.

\section{Acknowledgments}

The research was supported by the Czech Science Foundation (GA ČR Project No. 14-31593S) and the Operational Programme Education for Competitiveness - Project No. CZ.1.07/2.3.00/20.0296 


\section{References}

Antucheviciene, J.; Zakarevicius, A.; Zavadskas, E. K. 2011. Measuring congruence of ranking results applying particular MCDM methods, Informatica 22(3): 319-338.

Antucheviciene, J.; Zavadskas, E. K.; Zakarevicius, A. 2012. Ranking redevelopment decisions of derelict buildings and analysis of ranking results, Economic Computation and Economic Cybernetics Studies and Research 46(2): 37-62.

Ashayeri, J.; Tuzkaya, G.; Tuzkaya, U. R. 2012. Supply chain partners and configuration selection: an intuitionistic fuzzy choquet integral operator based approach, Expert Systems with Applications 39(3): 3642-3649. http://dx.doi.org/10.1016/j.eswa.2011.09.055.

Azimi, R.; Yazdani-Chamzini, A.; Fouladgar, M. M.; Zavadskas, E. K.; Basiri, M. H. 2011. Ranking the strategies of mining sector through ANP and TOPSIS in a SWOT framework, Journal of Business Economics and Management 12(4): 670-689. http://dx.doi.org/10.3846/16111699.2011.626552

Brauers, W. K. M.; Zavadskas, E. K. 2006. The MOORA method and its application to privatization in a transition economy, Control and Cybernetics 35(2): 445-469.

Brauers, W. K. M.; Zavadskas, E. K. 2010. Project management by MULTIMOORA as an instrument for transition economies, Technological and Economic Development of Economy 16(1): 5-24.

http://dx.doi.org/10.3846/tede.2010.01

Büyüközkan, G.; Feyzioğlu, O.; Nebol, E. 2008. Selection of the strategic alliance partner in logistics value chain, International Journal of Production Economics 113(1): 148-158. http://dx.doi.org/10.1016/j.ijpe.2007.01.016.

Chen, L. Y.; Wang, T.-C. 2009. Optimizing partners' choice in is/it outsourcing projects: the strategic decision of fuzzy VIKOR, International Journal of Production Economics 120(1): 233-242. http://dx.doi.org/10.1016/j.ijpe.2008.07.022.

Chen, S. H.; Wang, P. W.; Chen, C. M.; Lee, H. T. 2010. An analytic hierarchy process approach with linguistic variables for selection of an R\&D strategic alliance partner, Computers \& Industrial Engineering 58(2): 278-287. http://dx.doi.org/10.1016/j.cie.2009.10.006.

Chen, Y.-H.; Wang, T.-C.; Wu, C.-Y. 2011. Strategic decisions using the fuzzy PROMETHEE for is outsourcing, Expert Systems with Applications 38(10): 13216-13222. http://dx.doi.org/10.1016/j.eswa.2011.04.137.

Claycomb, C.; Frankwick, G. L. 2004. A contingency perspective of communication, conflict resolution and buyer search effort in buyer-supplier relationships, Journal of Supply Chain Management 40(4): 18-34. http://dx.doi.org/10.1111/j.1745-493X.2004.tb00253.x.

Cummings, J. L.; Holmberg, S. R. 2012. Best-fit alliance partners: the use of critical success factors in a comprehensive partner selection process, Long Range Planning 45(2-3): 136-159. http://dx.doi.org/10.1016/j.lrp.2012.01.001.

Ding, R.; Dekker, H. C.; Groot, T. 2013. Risk, partner selection and contractual control in interfirm relationships, Management Accounting Research 24(2): 140-155. http://dx.doi.org/10.1016/j.mar.2013.04.007

Geum, Y.; Lee, S.; Yoon, B.; Park, Y. 2013. Identifying and evaluating strategic partners for collaborative R\&D: index-based approach using patents and publications, Technovation 33(6-7): 211-224. http://dx.doi.org/10.1016/j.technovation.2013.03.012.

Gonzalez, M. 2001. Strategic alliances the right way to compete in the 21st century, Ivey Business Journal 66(1): 47-51.

Hoffmann, W. H.; Schlosser, R. 2001. Success factors of strategic alliances in small and medium-sized enterprises - an empirical survey, Long Range Planning 34(3): 357-381.

http://dx.doi.org/10.1016/S0024-6301(01)00041-3. 
Hosseini Nasab, H.; Milani, A. S. 2012. An improvement of quantitative strategic planning matrix using multiple criteria decision making and fuzzy numbers, Applied Soft Computing 12(8): 2246-2253. http://dx.doi.org/10.1016/j.asoc.2012.03.010.

Huang, J.-J.; Chen, C.-Y.; Liu, H.-H.; Tzeng, G.-H. 2010. A multiobjective programming model for partner selection-perspectives of objective synergies and resource allocations, Expert Systems with Applications 37(5): 3530-3536. http://dx.doi.org/10.1016/j.eswa.2009.09.044.

Kandakoglu, A.; Celik, M.; Akgun, I. 2009. A multi-methodological approach for shipping registry selection in maritime transportation industry, Mathematical and Computer Modelling 49(3-4): 586-597. http://dx.doi.org/10.1016/j.mcm.2008.09.001.

Karande, P.; Chakraborty, S. 2012. Application of multi-objective optimization on the basis of ratio analysis (MOORA) method for materials selection, Materials \& Design 37: 317-324.

Keršuliene, V.; Zavadskas, E. K.; Turskis, Z. 2010. Selection of rational dispute resolution method by applying new step-wise weight assessment ratio analysis (SWARA), Journal of Business Economics and Management 11(2): 243-258. http://www.tandfonline.com/doi/abs/10.3846/jbem.2010.12

Liou, J. J. H. 2012. Developing an integrated model for the selection of strategic alliance partners in the airline industry, Knowledge-Based Systems 28: 59-67. http://dx.doi.org/10.1016/j.knosys.2011.11.019.

Liou, J. J. H.; Tzeng, G.-H.; Tsai, C.-Y.; Hsu, C.-C. 2011. A hybrid ANP model in fuzzy environments for strategic alliance partner selection in the airline industry, Applied Soft Computing 11(4): 3515-3524. http://dx.doi.org/10.1016/j.asoc.2011.01.024.

Medcof, J. W. 1997. Why too many alliances end in divorce, Long Range Planning 30(5): 718-732. http://dx.doi.org/10.1016/S0024-6301(97)00050-2.

Safaei Ghadikolaei, A.; Khalili Esbouei, S.; Antucheviciene, J. 2014. Applying fuzzy MCDM for financial performance evaluation of Iranian companies, Technological and Economic Development of Economy 20(2): 274-291. http://dx.doi.org/10.3846/20294913.2014.913274

Sampson, R. C. 2004. Organizational choice in R\&D alliances: knowledge-based and transaction cost perspectives, Managerial and Decision Economics 25(6-7): 421-436. http://dx.doi.org/10.1002/mde.1199.

Tavana, M.; Momeni, E.; Rezaeiniya, N.; Mirhedayatian, S. M.; Rezaeiniya, H. 2013. A novel hybrid social media platform selection model using fuzzy ANP and COPRAS-G, Expert Systems with Applications 40(14): 5694-5702. http://dx.doi.org/10.1016/j.eswa.2013.05.015.

Wu, W. Y.; Shih, H.-A.; Chan, H.-C. 2009. The analytic network process for partner selection criteria in strategic alliances, Expert Systems with Applications 36(3), Part 1: 4646-4653. http://dx.doi.org/10.1016/j.eswa.2008.06.049.

Yazdani, M.; Larijani, A. L.; Zarimohaleh, S. T.; Monavarian, A. 2012. Developing optimized strategy by comprehensive framework of strategy; case study in a construction inspection company, Procedia Social and Behavioral Sciences 58: 73-83. http://dx.doi.org/10.1016/j.sbspro.2012.09.980.

Ye, F. 2010. An extended TOPSIS method with interval-valued intuitionistic fuzzy numbers for virtual enterprise partner selection, Expert Systems with Applications 37(10): 7050-7055. http://dx.doi.org/10.1016/j.eswa.2010.03.013.

Yue, Z. 2013. An intuitionistic fuzzy projection-based approach for partner selection, Applied Mathematical Modelling 37(23): 9538-9551. http://dx.doi.org/10.1016/j.apm.2013.05.007.

Yüksel, İ.; Dağdeviren, M. 2007. Using the analytic network process (ANP) in a SWOT analysis - a case study for a textile firm, Information Sciences 177(16): 3364-3382. http://dx.doi.org/10.1016/j.ins.2007.01.001.

Yurdakul, M.; Iç, Y. T. 2009. Analysis of the benefit generated by using fuzzy numbers in a TOPSIS model developed for machine tool selection problems, Journal of Materials Processing Technology 209(1): 310-317. 
Zavadskas, E. K.; Antucheviciene, J. 2007. Multiple criteria evaluation of rural building's regeneration alternatives, Building and Environment 42(1): 436-451. http://dx.doi.org/10.1016/j.buildenv.2005.08.001

Zavadskas, E. K.; Kaklauskas, A. 1996. Determination of an efficient contractor by using the new method of multicriteria assessment, in D. A. Langford, A. Retik (Eds.). International Symposium for "The Organisation and Management of Construction". Shaping Theory and Practice. Vol. 2: Managing the Construction Project and Managing Risk. CIB W 65; London, Weinheim, New York, Tokyo, Melbourne, Madras. London: E and FN SPON, 94-104.

Zavadskas, E. K.; Turskis, Z. 2010. A new additive ratio assessment (ARAS) method in multicriteria decision-making, Technological and Economic Development of Economy 16(2): 159-172. http://dx.doi.org/10.3846/tede.2010.10

Zavadskas, E. K.; Turskis, Z. 2011. Multiple criteria decision making (MCDM) methods in economics: an overview, Technological and Economic Development of Economy 17(2): 397-427.

http://dx.doi.org/10.3846/20294913.2011.593291

Peyman AKHAVAN is an Associate Professor at the Department of Management, Malek Ashtar University of Technology, Tehran, Iran. He has received MSc and PhD degrees from the Department of Industrial Engineering of Iran University of Science and Technology (IUST), Tehran, Iran. His research interests are in business process reengineering, knowledge management, information technology, and strategic planning. He has published a book and has more than 40 research papers at different conferences and in journals.

Sasan BARAK is member of Iran National Elites Foundation and has received his MSc degree in Industrial Engineering from the Yazd University, Yazd, Iran. His research interests are in data mining, machine learning, mathematical finance, fuzzy MCDM, health care and flexible manufacturing systems. His publications include some research papers at journals such as the European Journal of Operational Research and International Journal of Production Research.

Hamidreza MAGHSOUDLOU is a PhD student at the Faculty of Industrial and Mechanical Engineering, Qazvin Branch, Islamic Azad University, Qazvin, Iran. His research interests are in scheduling, Applied Operation Research, Optimization, and fuzzy MCDM. He is currently pursuing her PhD thesis concerning the scheduling of FMSs.

Jurgita ANTUCHEVIČIENĖ is Doctor, Professor at the Department of Construction Technology and Management, Vilnius Gediminas Technical University, Vilnius, Lithuania. She is a member of EURO Working Groups Multicriteria Decision Aiding and OR in Sustainable Development and Civil Engineering, Editorial Board member of three international research journals. Her research interests include sustainable development, construction business management and investment, multiple criteria analysis, decision-making theories and decision support systems. 